\title{
Effects of the Methanol Extract of Basella alba L (Basellaceae) on Steroid Production in Leydig Cells
}

\section{Edouard Akono Nantia ${ }^{1}$, Carine Travert ${ }^{2}$, Faustin-Pascal T. Manfo ${ }^{1}$, Serge Carreau ${ }^{2}$, Thomas K. Monsees ${ }^{3}$ and Paul Fewou Moundipa ${ }^{1, *}$}

1 Laboratory of Pharmacology and Toxicology, Department of Biochemistry, University of Yaoundé I, PO. Box 812 Yaounde, Cameroon; E-Mails: akonoed@yahoo.fr (E.A.N.); faustinpascal@yahoo.fr (F.-P.T.M.)

2 Biochemistry Laboratory-EA 2608-USC INRA 2006, IBFA, University of Caen, 14032, Caen, France; E-Mails: c.travert@uitcaen.unicaen.fr (C.T.); serge.carreau@unicaen.fr (S.C.)

3 Department of Medical Biosciences, University of the Western Cape, South Africa; E-Mail: thomas.monsees@tu-dresden.de

* Author to whom correspondence should be addressed; E-Mail: pmoundipa@hotmail.com or pmoundipa@uy1.uninet.cm; Tel.: +237-773-103-83/220-160-43.

Received: 10 December 2010; in revised form: 21 December 2010 / Accepted: 8 January 2011 / Published: 14 January 2011

\begin{abstract}
In this study, Leydig cells were purified from 70 day-old Sprague Dawley male rats and incubated with 10 and $100 \mu \mathrm{g} / \mathrm{mL}$ of methanol extract of Basella alba (MEBa) for 4 hours followed by the evaluation of cell viability, steroid (testosterone and estradiol) production, and the level of aromatase mRNA. Results showed that MEBa did not affect Leydig cell viability. At the concentration of $10 \mu \mathrm{g} / \mathrm{mL}$, MEBa significantly stimulated testosterone and estradiol production ( $p<0.01$ and $p<0.03$, respectively), and enhanced aromatase mRNA level $(\mathrm{p}<0.04)$. These observations suggest that MEBa directly stimulated testosterone, estradiol and aromatase mRNA levels in isolated Leydig cells.
\end{abstract}

Keywords: aromatase mRNA; Basella alba; estradiol; rat Leydig cells; testosterone

\section{Introduction}

Plants have been used in the treatment of human illnesses for millennia, and many have shown a positive effect on male reproductive functions [1,2]. Basella alba is a plant used in traditional 
medicine in the West Cameroon region to treat sexual asthenia and infertility in man. Its methanol extract $(\mathrm{MEBa})$ stimulated testosterone production in testicular fractions and Leydig cell cultures, and in normal adult albinos male rats [3-5]. Androgens are essential for male reproductive function and hypotestosteronemia and/or androgenic resistance are found in certain forms of male infertility [6]. In Leydig cells, testosterone is partly metabolized into estradiol by aromatase. This enzyme sustains the equilibrium between testicular testosterone and estradiol levels. Estradiol is also essential in the development and maintenance of male reproductive function with regard to animals deficient in the estrogen receptor gene or aromatase gene [7-9], and men with congenital aromatase deficiency [10]. Furthermore, the combined use of testosterone and estradiol in two hypogonadic patients with aromatase gene deficiency restored the serum hormone (testosterone, estradiol, LH and FSH) levels and the bone mineral density, while the single administration of testosterone or estradiol failed $[9,10]$. In addition, low levels of testosterone and estradiol (although the diminution of estradiol is less common than that of testosterone) are noted in age related hypogonadic individuals [11,12]. By stimulating testosterone production, MEBa may modulate androgen estrogen testicular homeostasis. This effect could contribute to the improvement of male reproductive function.

This work was thus aimed at determining whether MEBa could regulate androgen estrogen balance. To this end, freshly purified adult rat Leydig cells were incubated with MEBa, followed by determination of testosterone and estradiol release in the media, and cytochome P450 aromatase mRNA levels.

\section{Results}

\subsection{Effect of MEBA on Leydig Cell Viability}

As illustrated in Figure 1, the viability of Leydig cells was affected not by 10 or $100 \mu \mathrm{g} / \mathrm{mL}$ of MEBa, or the vehicle $(0.025 \%$ DMSO).

Figure 1. Viability of the Leydig cells treated with MEBa. Each value represents the mean \pm SD of 3 experiments. Cells ( $310^{5} /$ well, in duplicate) were incubated for 4 hours in the presence $(+)$ or absence (-) of DMSO, or MEBa dissolved in DMSO. MEBa: methanol extract of B. alba.

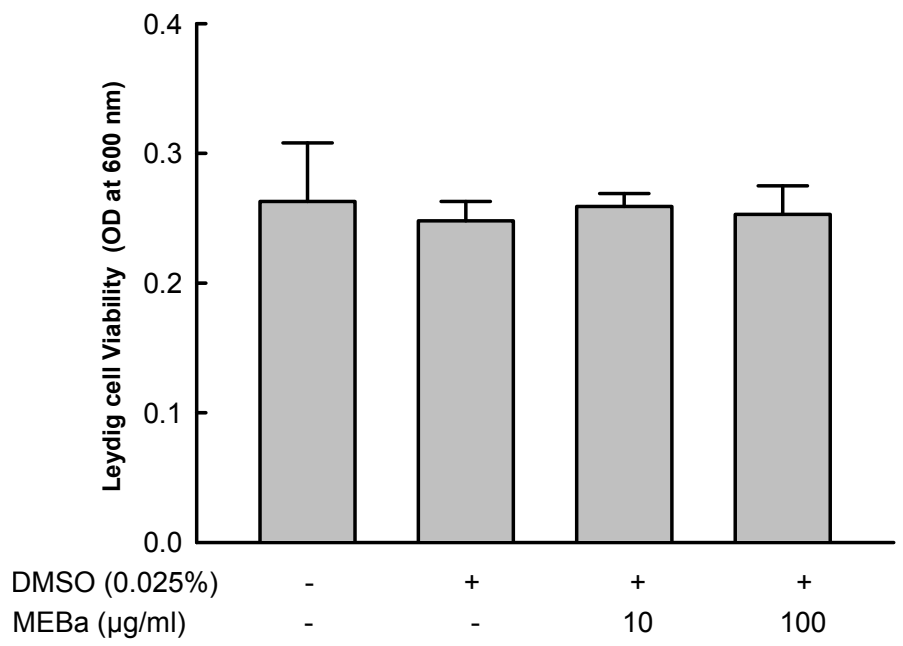




\subsection{Testosterone and Estradiol Production by Leydig Cells}

The production of testosterone in control cells (basal) was $0.33 \pm 0.05 \mathrm{ng} / 10^{6} 3 \beta$-HSD positive cells (Table 1). In the presence of $1 \mathrm{UI} / \mathrm{mL}$ and $10 \mathrm{UI} / \mathrm{mL}$ hCG, the production of testosterone increased 5-fold $(\mathrm{p}<0.005)$ and 9-fold $(\mathrm{p}<0.001)$, respectively. The concentration of $10 \mu \mathrm{g} / \mathrm{mL} \mathrm{MEBa}$ significantly stimulated basal testosterone production $(\mathrm{p}<0.01)$, and enhanced $1 \mathrm{UI} / \mathrm{mL}$ hCG-evoked testosterone level $(\mathrm{p}<0.002)$.

Table 1. Testosterone level of Leydig cells.

\begin{tabular}{|l|l|l|l|}
\hline hCG & \multicolumn{1}{|c|}{ 0 UI/mL } & \multicolumn{1}{c|}{$\mathbf{1 ~ U I / m L}$} & 10 UI/mL \\
\hline Control & $0.33 \pm 0.05$ & & \\
\hline $0.025 \%$ DMSO & $0.32 \pm 0.01$ & $1.63 \pm 0.07^{\mathrm{b}}$ & $2.81 \pm 0.10^{\mathrm{d}}$ \\
\hline $\mathrm{MEBa} 10 \mu \mathrm{g} / \mathrm{mL}$ & $0.63 \pm 0.04^{\mathrm{a}}$ & $1.99 \pm 0.09^{\mathrm{c}}$ & $2.86 \pm 0.17^{\mathrm{d}}$ \\
\hline $\mathrm{MEBa} 100 \mu \mathrm{g} / \mathrm{mL}$ & $0.35 \pm 0.02$ & $1.61 \pm 0.05^{\mathrm{b}}$ & $2.76 \pm 0.08^{\mathrm{d}}$ \\
\hline
\end{tabular}

Data are expressed as ng $/ 10^{6}$ cells. Each value represents the mean \pm SD of 3 experiments each done in duplicate. Cells $\left(3 \times 10^{6} /\right.$ well $)$ were maintained for 4 hours in the incubation medium alone (Control), or treated with MEBa dissolved in DMSO or with hCG. Data are compared to those of the Leydig cells treated with DMSO; ${ }^{\mathrm{a}} \mathrm{p}<0.01 ;{ }^{\mathrm{b}} \mathrm{p}<0.005 ;{ }^{\mathrm{c}} \mathrm{p}<0.002 ;{ }^{\mathrm{d}} \mathrm{p}<0.001$ (Student Newman-Keuls's test). hCG: human chorionic gonadotrophin, MEBa: methanol extract of B. alba.

As illustrated in Table 2, the basal estradiol production was $62.14 \pm 8.68 \mathrm{pg} / 10^{6} 3 \beta$-HSD positive cells. The estradiol level was increased 4-fold $(\mathrm{p}<0.008)$ and 6 -fold $(\mathrm{p}<0.001)$ after incubation of cells with $1 \mathrm{UI} / \mathrm{mL}$ and $10 \mathrm{UI} / \mathrm{mL}$ hCG, respectively. The MEBa stimulated basal estradiol production ( $\mathrm{p}<0.03$ ), and enhanced $1 \mathrm{UI} / \mathrm{mL}$ hCG evoked estradiol release at the concentration of $10 \mu \mathrm{g} / \mathrm{mL}$ $(\mathrm{p}<0.002)$.

The concentration of $100 \mu \mathrm{g} / \mathrm{mL}$ of MEBa did neither affect testosterone nor estradiol release.

Table 2. Estradiol level of Leydig cells.

\begin{tabular}{|l|l|c|c|}
\hline hCG & \multicolumn{1}{|c|}{ 0 UI/mL } & 1 UI/mL & 10 UI/mL \\
\hline Control & $62.14 \pm 8.68$ & & \\
\hline $0.025 \%$ DMSO & $54.21 \pm 11.50$ & $201.37 \pm 15.19^{\mathrm{b}}$ & $331.44 \pm 39.84^{\mathrm{d}}$ \\
\hline $\mathrm{MEBa} 10 \mu \mathrm{g} / \mathrm{mL}$ & $88.67 \pm 6.05^{\mathrm{a}}$ & $246.42 \pm 21.67^{\mathrm{c}}$ & $337.64 \pm 35.31^{\mathrm{d}}$ \\
\hline $\mathrm{MEBa} 100 \mu \mathrm{g} / \mathrm{mL}$ & $69.26 \pm 8.34$ & $204.89 \pm 28.38^{\mathrm{b}}$ & $330.94 \pm 42.17^{\mathrm{d}}$ \\
\hline
\end{tabular}

Data are expressed as pg/10 $10^{6}$ cells. Each value represents the mean \pm SD of 3 experiments each done in duplicate. Cells $\left(3 \times 10^{6} /\right.$ well $)$ were maintained for 4 hours in the incubation medium alone (Control), or treated with MEBa dissolved in DMSO or with hCG. Data are compared to those of the Leydig cells treated with DMSO; ${ }^{\mathrm{a}} \mathrm{p}<0.03 ;{ }^{\mathrm{b}} \mathrm{p}<0.008 ;{ }^{\mathrm{c}} \mathrm{p}<0.002 ;{ }^{\mathrm{d}} \mathrm{p}<0.001$ (Student Newman-Keuls's test). hCG: human chorionic gonadotrophin, MEBa: methanol extract of B. alba. 


\subsection{Aromatase mRNA Levels}

Aromatase mRNA levels (Figure 2A,B) were quantified and normalized against L19 mRNA as a reference. The mRNA levels of aromatase in the Leydig cells were significantly stimulated $(\mathrm{p}<0.04)$ by $10 \mu \mathrm{g} / \mathrm{mL}$ of MEBa as compared to cells treated with $0.025 \%$ DMSO.

Figure 2. Aromatase transcripts (A) and normalized levels (B) in the Leydig cells. Aromatase transcripts visualization on a $\%$ agarose gel after RT-PCR. M corresponds to DNA ladder (100 bp ladder). Each value represents the mean \pm SD of 3 experiments each done in duplicate. Cells $\left(3 \times 10^{6} /\right.$ well $)$ were maintained for 4 hours in the incubation medium alone $(\mathbf{C})$, or treated with MEBa (MEBa1: $10 \mu \mathrm{g} / \mathrm{mL}, \mathrm{MEBa} 2: 100 \mu \mathrm{g} / \mathrm{mL}$ ) dissolved in $0.025 \%$ DMSO. Data are compared to those of Leydig cells treated with $0.025 \%$ DMSO. ${ }^{\mathrm{a}} \mathrm{p}<0.04$ (Student Newman-Keuls test). MEBa: methanol extract of $B$. alba.

A

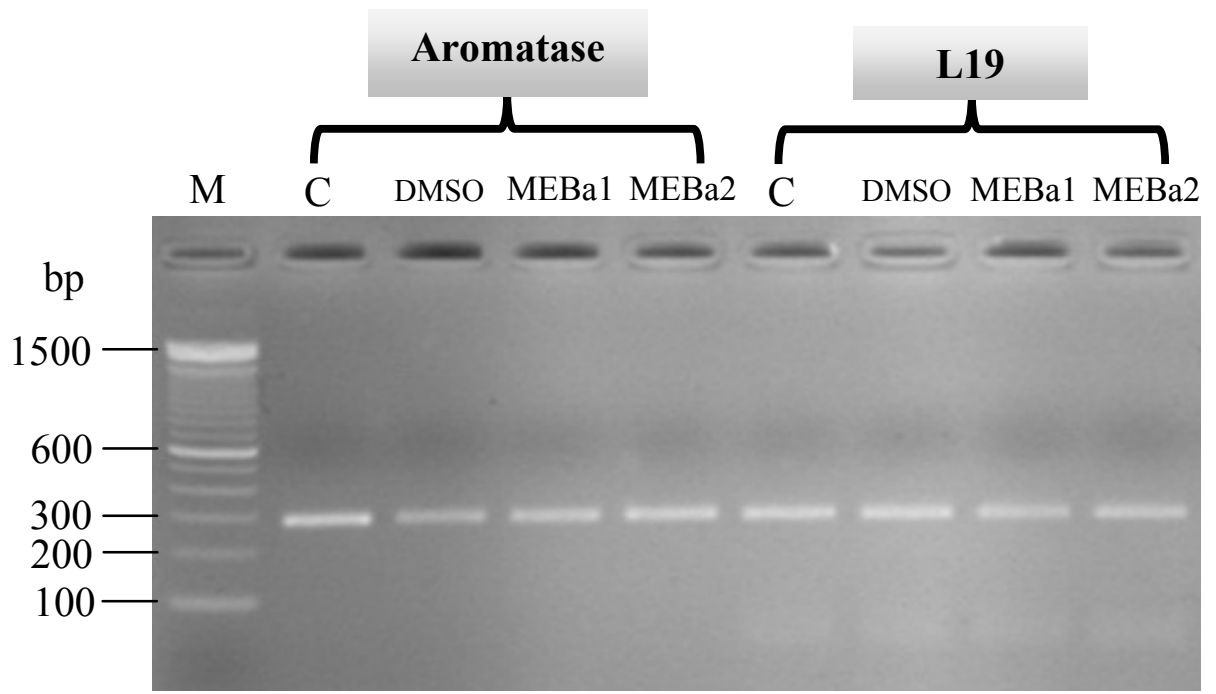

B

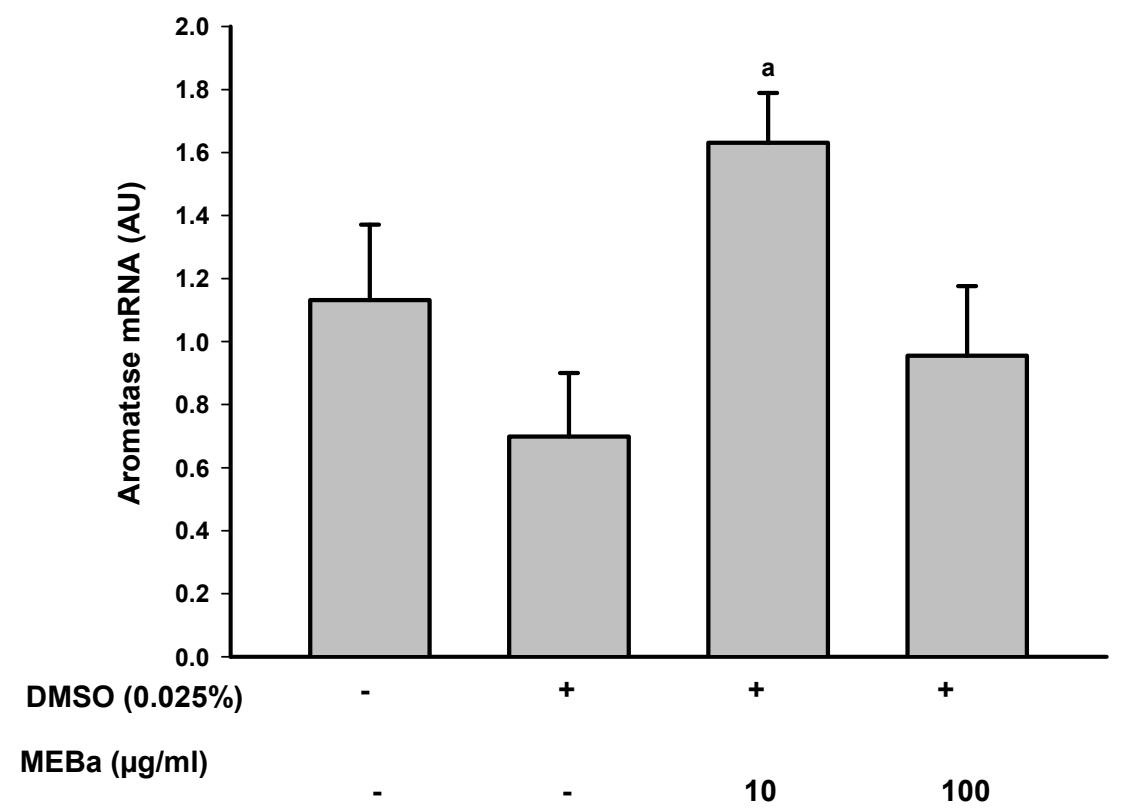




\section{Discussion}

Testosterone is essential for several physiological processes in man. It is involved in spermatogenesis, sexual arousal and virility, psychological well being, development and maintenance of the bone stature and erythropoïesis. Some biological effects of testosterone are mediated through its aromatization into estradiol [9,18-22]. The homeostasis between testosterone and estradiol is maintained by the enzymatic complex named aromatase located in the endoplasmic reticulum of the cells. Aromatase appears to be expressed in numerous tissues, and its activity is of great significance for the male reproductive function [10,23].

Moundipa et al. [4] showed that MEBa stimulates testosterone production by Leydig cells after 12 hours of incubation, with a maximum effect at $10 \mu \mathrm{g} / \mathrm{mL}$. The androgenic activity of MEBa at $10 \mu \mathrm{g} / \mathrm{mL}$ was confirmed in our study after 4 hours of incubation. The testosterone- enhancing effect of this plant extract may be partly due the presence of terpenoid compounds [4], which may augment the pool of cholesterol-a substrate for steroid synthesis. However, the stimulatory effect of MEBa on testosterone was slightly reduced at the concentration $100 \mu \mathrm{g} / \mathrm{mL}$. This suggests a desensitizing effect of the extract at high concentration, since Leydig cells viability was not affected.

In the presence of a suboptimal concentration of hCG $(1 \mathrm{UI} / \mathrm{mL}), \mathrm{MEBa}(10 \mu \mathrm{g} / \mathrm{mL})$ enhanced both testosterone and estradiol production, but this stimulatory effect was annulled when a high concentration of hCG $(10 \mathrm{UI} / \mathrm{mL})$ was used. Human chorionic gonadotropin or LH binding to its receptor triggered the cAMP signaling cascade leading to rapid effects, including cholesterol mobilization, and elevated steroidogenic enzymes activity, and longer term transcriptional effects [23]. Active compounds of MEBa could optimize cellular pathways initiated by hCG through regulation of elements such as protein kinases and cAMP response elements.

The stimulatory effect of MEBa on estradiol level may result from its effect on aromatase gene transcription and translation into a biologically active enzyme. Indeed $10 \mu \mathrm{g} / \mathrm{mL}$ of MEBa increased the amount of aromatase transcripts, and this effect decreased when cells were incubated with $100 \mu \mathrm{g} / \mathrm{mL}$ of the extract. This observation is further corroborated by the stimulation of estradiol release, as well as the elevated level of its immediate precursor testosterone. In fact, estrogens positively regulate male reproductive function as shown by induction of spermatogenesis in the hypogonadal (hpg) mouse and the stimulation of spermatogonia cell proliferation in cryptorchid mice [25,26]. In addition, Asah [27] reported an increased sperm count, normal serum FSH, and fecundity in man suffering from oligospermia with small testes and elevated serum FSH after low dose estrogen testosterone combination therapy.

\section{Materials and Methods}

\subsection{Plant Material and Preparation of the Methanol Extract of Basella alba}

Fresh leaves of B. alba (identified at the Cameroonian National Herbarium as specimen $\mathrm{N}^{\circ} 40720$ ) were collected in Dschang (West Region of Cameroon) in August 2005, dried at room temperature and ground in powder. The methanol extract of $B$. alba was obtained through successive extraction in hexane, methylene chloride and methanol as previously described [3]. The extraction efficiency in methanol was $3 \%$. 


\subsection{Chemicals}

Dulbecco's Modified Eagle's Medium (DMEM), Ham-F12, Collagenase/ dispase, DNAse, Soybean Trypsin Inhibitor (STI) and NAD were purchased from Sigma Aldrich (France). RIA antibodies for testosterone and estradiol quantification were purchased from P.AR.I.S (Compiègne-France). Kits for the extraction of RNA and PCR were obtained from Promega (France). Other reagents were all of high quality grade.

\subsection{Animals}

Animals used in the experiment were 70 day-old Sprague-Dawley rats obtained from the animal house of the University of Caen, France. They were bred under standard conditions (12 h light:12 h darkness cycle and controlled room temperature) with standard rat food and water ad libitum. Their use was in accordance with the French Government Regulations (Services Vétérinaires de la Santé et de la Production Animale, Ministère de l'Agriculture) and approved by the Local Ethical Committee of the University of Caen.

\subsection{Purification of Leydig Cells}

Leydig cells were purified as described elsewhere [13]. Briefly, rats were sacrificed and testes dissected, removed and subjected to collagenase/dispase $(0.05 \%)$ digestion in the presence of STI $(0.005 \%)$ and DNase $(0.001 \%)$ in DMEM/Ham F12 medium. The digested mixture was allowed to settle, the supernatant collected and centrifuged $\left(900 \mathrm{rpm}, 10 \mathrm{~min}, 18{ }^{\circ} \mathrm{C}\right)$. The resulting cell pellet was resuspended in the incubation medium and filtered through 30 nylon mesh membrane to obtain the crude interstitial cells. The Leydig cells were further purified on a discontinuous Percoll gradient (20-80\%). After centrifugation of the gradient (2400 rpm, $\left.20 \mathrm{~min}, 18{ }^{\circ} \mathrm{C}\right)$, Leydig cells fractions were collected and used for the assays. After purification, viable cells were counted using a hemocytometerbased trypan blue dye exclusion method and their purity was assessed by the $3 \beta$-hydroxysteroiddehydrogenase ( $3 \beta-H S D)$ histochemical staining. The percentage of viable Leydig cells was more than $95 \%$ and their purity higher than $85 \%$.

\subsection{Study of the Effect of MEBA on Leydig Cell Viability}

Purified Leydig cells $\left(3 \times 10^{5}\right.$ cells $/$ well $\left./ \mathrm{mL}\right)$ were incubated for 4 hours $\left(32{ }^{\circ} \mathrm{C}\right.$ under $95 \%$ air $/ 5 \%$ $\mathrm{CO}_{2}$ ) either with $0.025 \%$ DMSO (vehicle), $10 \mu \mathrm{g} / \mathrm{mL}$ and $100 \mu \mathrm{g} / \mathrm{mL}$ of MEBa. Plant extract concentrations were selected from previous studies conducted by Moundipa et al. [4]. After the incubation, culture plates were centrifuged $\left(900 \mathrm{rpm}, 10 \mathrm{~min}, 18{ }^{\circ} \mathrm{C}\right)$, supernatants discarded and cell pellets incubated with crystal violet solution $(0.1 \% \mathrm{w} / \mathrm{v}$ in $\mathrm{PBS} 0.01 \mathrm{M}, \mathrm{pH} 7.4)$ for $30 \mathrm{~min}$ at $18{ }^{\circ} \mathrm{C}$. The crystal violet was taken up by living cells during the incubation, and the excess dye eliminated through 3 washing steps with PBS. Diluted acetic acid solution (10\%) was used to release the crystal violet taken up by cells, and the optical density of each well was determined at $600 \mathrm{~nm}$ using luminometer (BERTHOLD Technologies, Mithras LB 940) [14]. 


\subsection{Study of the Effect of MEBA on Steroid Production and Aromatase mRNA Level}

Leydig cells $\left(3 \times 10^{6}\right.$ cells/well $\left./ 2 \mathrm{~mL}\right)$ were treated either with vehicle $(0.025 \% \mathrm{DMSO})$ or MEBa (10 or $100 \mu \mathrm{g} / \mathrm{mL}$ ) or hCG (1 or $10 \mathrm{IU} / \mathrm{mL})$. Human chorionic gonadotropin was used as a positive control to challenge Leydig cells and the concentrations used were after laboratory trials and from the previous study [15]. Plates were incubated $\left(32{ }^{\circ} \mathrm{C}\right.$ under $95 \%$ air $\left./ 5 \% \mathrm{CO}_{2}\right)$ for 4 hours (time selected from preliminary study, which showed similar effect in steroid production after 4 hours or 12 hours of incubation). Culture plates were then centrifuged and supernatants used for the quantification of estradiol and testosterone levels by ${ }^{3}$ H-RIA using specific antibodies. Briefly, steroids were dissolved in phosphate albumin buffer $(0.1 \mathrm{M}, \mathrm{pH} 7.3$, containing $2 \%$ bovine serum albumin), incubated with radio-labeled testosterone or estradiol $(3000 \mathrm{cpm} / 100 \mu \mathrm{L})$ and their respective antibody (Cross reactions between anti-estradiol and testosterone and vice-versa were always less than $0.01 \%$ ). Unbound radio-labeled steroid was adsorbed to activated charcoal and separated by centrifugation. Antibody-bound radio-labeled steroid was thereafter determined using liquid scintillation counter. Estradiol was extracted from culture medium using diethylether (300:1, v/v) prior ${ }^{3} \mathrm{H}-\mathrm{RIA}$ quantification [15]. The inter- and intra-assay coefficients of variation were respectively 5 and $8 \%$ for testosterone, and 4 and $8 \%$ for estradiol. The detection limit was $3 \mathrm{pg}$ and $4 \mathrm{pg}$ per tube for estradiol and testosterone, respectively. Pellets containing cells were lysed with denaturing agent and RNA were recovered in an aqueous phase. RNA was further purified by precipitation with isopropanol and washing with cold ethanol [16]. Two $\mu \mathrm{g}$ of total RNA were further subjected to reverse transcriptase polymerase chain reaction (RT-PCR) in the medium containing $500 \mu \mathrm{M}$ dNTP, $0.2 \mu$ g oligodT, $200 \mathrm{U}$ MMLV-RT (Moloney murine leukeumia virus reverse transcriptase) as well as 20U RNasin (ribonuclease inhibitor) and primers [aromatase primers: 51555-GCTTCTCATCGCAGAGTATCCGG-3 (sense), 51844-CAAGGGTAAATTCATTGGGCTTGG-3 (antisense); L19 primers: 5119-GAAATCGCCAATGCCAACTC-3 (sense), 5408-ACCTTCAGGTACAGGCTGTG-3 (antisense)]. Five microliters RT-PCR products were then amplified in the presence of GoTaq Flexi DNA polymerase during 36 PCR cycles (for mRNA aromatase) or 24 PCR cycles (for mRNA L19, a DNA house-keeping gene [17] made up of denaturation at $95{ }^{\circ} \mathrm{C}(30 \mathrm{~s})$, hybridization at $60{ }^{\circ} \mathrm{C}(30 \mathrm{~s})$ and polymerization at $72{ }^{\circ} \mathrm{C}(45 \mathrm{~s})$. Intensities of the obtained DNA products were determined after agarose gel electrophoresis using Image $\mathrm{J}$ software.

\subsection{Statistical Analyses}

Normality between data was checked by the Kolmogorov-Smirnov test, and differences between parameters of different treatments assessed by the Student Newman-Keuls's test. Analyses were done using the Sigmastat 3.1 software (Systat Software Inc., San Jose, CA, USA).

\section{Conclusions}

MEBa stimulated estradiol production and aromatase mRNA by Leydig cells at $10 \mu \mathrm{g} / \mathrm{mL}$. The traditional use of $B$. alba in the treatment of male infertility and sexual asthenia could be due to its capacity to stimulate not only androgens production, but also estrogens, thus maintaining the androgen estrogen balance necessary for normal male reproductive function. MEBa represents a semi-purified 
extract, and its further fractionation will enable isolation of pure active compound(s) exhibiting steroidogenic effect and male fertility enhancement.

\section{Acknowledgements}

This work was supported by AUF doctoral fellowship program and SALF 2007 grant.

\section{References}

1. Nantia, E.A.; Moundipa, F.P.; Monsees, K.T.; Carreau, S. Medicinal plants as potential male antiinfertility agents: A review. Andrologie 2009, 19, 148-158.

2. Swerdlow, J. Nature's Medicine. Plants That Heal; National Geographic Society: Washington, D.C., USA, 2000.

3. Nantia, A.E.; Moundipa, F.P.; Beboy, E.S.N.; Monsees, K.T.; Carreau, S. Study of the androgenic effect of the methanol extract of Basella alba L. (Basellaceae) on the male rat reproductive function. Andrologie 2007, 17, 129-133.

4. Moundipa, F.P.; Beboy, E.S.N.; Zelefack, F.; Ngouela, S.; Tsamo, E.; Schill, W.B.; Monsees, T.K. Effects of Basella alba and Hibiscus macranthus extracts on testosterone production by adult rat and bull Leydig cells. Asian J. Androl. 2005, 7, 411-417.

5. Moundipa, F.P.; Ngouela. S.; Kamtchouing, P.; Tsamo, E.; Tchouanguep, M.F.; Carreau, S. Effects of extracts from Hibiscus macranthus and Basella alba mixture on testosterone production in vitro in adult rat testes slices. Asian J. Androlol. 2006, 8, 111-114.

6. Kandeel, R.F.; Koussa, T.K.V.; Swerdloff, S.R. Male sexual function and its disorders: Physiology, pathophysiology, clinical investigation, and treatment. Endocr. Rev. 2001, 22, 342-388.

7. Jones, E.E.M.; Simpson, R.E. Oestrogens in male reproduction. Baillière's Clin. Endocrinol. Metab. 2000, 14, 505-516.

8. Walker, R.V.; Korach, S.K. Estrogen receptor knockout mice as a model for endocrine research. ILAR J. 2004, 45, 455-461.

9. Carani, C.; Granata, M.R.A.; Rochira, V.; Caffagni, G.; Aranda, C.; Antunez, P.; Maffei, L.E. Sex steroids and sexual desire in a man with a novel mutation of aromatase gene and hypogonadism. Psychoneuroendocrinology 2005, 30, 413-417.

10. Rochira, V.; Zirilli, L.; Madeo, B.; Aranda, C.; Caffagni, G.; Fabre, B.; Montangero, V.E.; Roldan, E.J.; Maffei, L.; Carani, C. Case Report: Skeletal effects of long-term estrogen and testosterone replacement treatment in a man with congenital aromatase deficiency: Evidences of a priming effect of estrogen for sex steroids action on bone. Bone 2007, 40, 1662-1668.

11. Khosla, S.; Melton, L.J.; Atkinson, E.J.; O’Fallon, W.M.; Klee, G.G.; Riggs, B.L. Relationship of serum sex steroid levels and bone turnover markers with bone mineral density in men and women: A key role for bioavailable estrogen. J. Clin. Endocrinol. Metab. 1998, 83, 2266-2274.

12. Harman, M.S.; Metter, J.E.; Tobin, D.J.; Pearson, J.; Blackman, R.M. Longitudinal effects of aging on serum total and free testosterone levels in healthy men. Baltimore longitudinal study of aging, J. Clin. Endocrinol. Metab. 2001, 86, 724-731. 
13. Papadopoulos, V.; Carreau, S.; Drosdowsky, M.A. Effect of phorbol ester and phospholipase C on LH-stimulated steroidogenesis in purified rat Leydig cells. Febs. Lett. 1985, 2, 312-316.

14. Saotome, K.; Morita, H.; Umeda, M. Cytotoxicity test with simplified crystal violet staining method using microtitre plates and its application to injection drugs. Toxicol. in Vitro 1989, 3, $317-321$.

15. Travert, C.; Carreau, S.; Le Goff, D. Induction of apoptosis by 25 -hydroxycholesterol in adult rat Leydig cells: Protective effect of 17 $\beta$-estradiol. Reproduct. Toxicol. 2006, 22, 564-570.

16. Chomczynski, P.; Sacchi, N. Single-step method of RNA isolation by acid guanidium thiocyanate-phenol-chloroform extraction. Anal. Biochem. 1987, 8, 155-161.

17. Tena-Sempere, M.; Barreiro, M.L.; González, L.C.; Gaytán, F.; Zhang, F.P.; Caminos, E.J.; Pinilla, L.; Casanueva, F.F.; Diéguez, C.; Aguilar, E. Novel expression and functional role of ghrelin in rat testis. Endocrinology 2002, 143, 717-725.

18. Sharpe, R.M.; Donachie, K.; Cooper, I. Re-evaluation of the intratesticular level of testosterone required for quantitative maintenance of spermatogenesis in the rat. J. Endocrinol. 1988, 117, 19-26.

19. Kung, W.C. Androgen and bone mass in men. Asian J. Androl. 2003, 5, 148-154.

20. Sinha-Hikim, I.; Taylor, E.W.; Gonzalez-Cadavid, F.N.; Zheng, W.; Bhasin, S. Androgen receptor in human skeletal muscle and cultured muscle satellite cells: Up-regulation by androgen treatment. J. Clin. Endocrinol. Metab. 2004, 89, 5245-5255.

21. Motofei, I.G.; Rowland, D.L. The physiological basis of human sexual arousal: Neuroendocrine sexual asymmetry. Int. J. Androl. 2005, 28, 78-87.

22. Bilińska, B.; Wiszniewska, B.; Kosiniak-Kamysz, K.; Kotula-Balak, M.; Gancarczyk, M.; Hejmej, A.; Sadowska, J.; Marchlewicz, M.; Kolasa, A.; Wenda-Rózewicka, L. Hormonal status of male reproductive system: Androgens and estrogens in the testis and epididymis. In vivo and in vitro approaches. Reproduct. Biol. 2006, 6, 43-58.

23. Carreau, S.; Silandre, D.; Bourguiba, S.; Hamden, K.; Said, L.; Lambard, S.; Galeraud-Denis, I.; Delalande, C. Estrogens and male reproduction: A new concept. Braz. J. Med. Biol. Res. 2007, 40, 761-768.

24. Winters, J.S. Neuroendocrine control of testicular function. In Male Repoductive Function Pathophysiology and Treatment; Kandeel, R.F., Swerdloff, S.R., Pryor, L.J., Eds.; Informa, Healthcare: New York, NY, USA, 2007; pp. 21-34.

25. Baines, H.; Nwagwu, M.O.; Furneaux, E.C.; Stewart, J.; Kerr, J.B.; Mayhew, T.M.; Ebling, F.J. Estrogenic induction of spermatogenesis in the hypogonadal (hpg) mouse: Role of androgens. Reproduction 2005, 130, 643-654.

26. Li, Z.-E.; Li, X.-D.; Zhang, Q.-S.; Wang, Y.-C.; Zhang, M.-X.; Lu, Y.-J.; Duan, C.M.; Yang, X.Z.; Feng, L.X. 17 beta-estradiol stimulates proliferation of spermatogonia in experimental cryptorchid mice. Asian J. Pharmacol. 2007, 9, 659-667.

27. Asah, P. Oligospermia due to partial maturation arrest responds to low dose estrogen-testosterone combination therapy resulting in live-birth: A case report. Asian J. Androl. 2002, 4, 307-308.

(C) 2011 by the authors; licensee MDPI, Basel, Switzerland. This article is an open access article distributed under the terms and conditions of the Creative Commons Attribution license (http://creativecommons.org/licenses/by/3.0/). 